\title{
IMPLEMENTASI UNDANG-UNDANG REPUBLIK INDONESIA NOMOR 18 TAHUN 2013 TERHADAP PRAKTIK PEMBALAKAN LIAR (ILLEGAL LOGGING)
}

\author{
Angela Kezia ${ }^{1}$, Angelica Monica Fortunata ${ }^{2}$, dan Putri Claudia Victoria ${ }^{3}$ \\ ${ }^{1}$ Jurusan Hukum, Universitas Tarumanagara \\ Surel:angelakezia27@gmail.com \\ ${ }^{2}$ Jurusan Hukum, Universitas Tarumanagara \\ Surel:putriclaudiavictoria.010601@gmail.com \\ ${ }^{3}$ Jurusan Hukum, Universitas Tarumanagara \\ Surel:jessicalicialim27@gmail.com
}

\begin{abstract}
This research was conducted with the aim of analyzing one area in Riau Province, precisely in Pekanbaru City, which experienced rapid forest degradation caused by illegal logging by criminals. This research was conducted using a normative approach that is related to the problems (legal issues) regarding illegal logging in Pekanbaru City. This type of approach focuses on the analysis of legal principles and theories of law and legislation that are appropriate and related to issues in legal research, and is carried out by examining secondary data in the form of books, journals, government publications related to the legal issues of this research. The results and discussion in this study regarding the implementation of the enactment of Law Number 18 of 2013 concerning Prevention and Eradication of Forest Destruction against individual legal subjects and business entities (corporations) that commit criminal acts in the area of Pekanbaru City. In terms of ensnaring the perpetrators of illegal logging, the existing policies are not sufficient to overcome the problem where the perpetrators of criminal acts are more sophisticated and the law enforcement against the perpetrators of criminal acts is low, so that it does not provide a deterrent effect for the perpetrators. In overcoming the problem, the participation of local communities in forest monitoring and management must be realized because it is not enough only with the law enforcement officers and in terms of regulations, specific regulations must be synchronized with general regulations so that they do not conflict with each other and create flaws in their application.
\end{abstract}

Keywords: Illegal Logging; Implementation; Pekanbaru City

\begin{abstract}
ABSTRAK
Penelitian ini dilakukan dengan tujuan yaitu menganalisis salah satu wilayah di Provinsi Riau tepatnya di Kota Pekanbaru, yang mengalami degradasi hutan cukup cepat diakibatkan oleh pembalakan liar oleh para pelaku tindak pidana. Penelitian ini dilakukan dengan menggunakan pendekatan normatif yang bersangkut paut dengan pemasalahan (isu hukum) mengenai pembalakan liar di Kota Pekanbaru. Jenis pendekatan ini berupa analisis terhadap asas hukum dan teori hukum dan peraturan perundang-undangan berkaitan dengan isu dalam penelitian hukum, dan dilakukan dengan cara meneliti data sekunder berupa buku, jurnal, publikasi pemerintah yang berkaitan dengan isu hukum penelitian ini. Hasil dan pembahasan dalam penelitian ini adalah mengenai implementasi Undang-Undang Nomor 18 Tahun 2013 tentang Pencegahan dan Pemberantasan Perusakan Hutan terhadap pelaku tindak pidana perseorangan maupun badan hukum (korporasi) di wilayah Kota Pekanbaru. Dalam hal menjerat pelaku pembalakan liar, kebijakan yang ada belum cukup untuk mengatasi permasalahan yang dimana pelaku tindak pidana lebih canggih serta rendahnya penegakkan hukum terhadap pelaku tindak pidana sehingga kurang memberikan efek jera bagi para pelaku. Dalam mengatasi permasalahan maka ikut andil masyarakat setempat dalam pengawasan dan pengelolaan hutan harus direalisasikan sebab tidaklah cukup hanya dengan aparat saja serta dalam hal peraturan, haruslah peraturan yang bersifat khusus disinkronisasikan terhadap peraturan yang bersifat umum agar tidak bertentangan antar satu sama lain dan menimbulkan celah dalam penerapannya.
\end{abstract}

Kata Kunci: Pembalakan liar; Implementasi; Kota Pekanbaru 


\section{PENDAHULUAN}

\section{Latar Belakang}

Pembalakan liar (Illegal logging) merupakan salah satu faktor penyebab degradasi hutan pada suatu wilayah. Berdasarkan Undang - Undang Nomor 18 tahun 2013 tentang Pencegahan dan Pemberantasan Perusakan Hutan pada Pasal (1) ayat 4, pembalakan liar adalah semua kegiatan pemanfaatan hasil hutan kayu secara tidak sah yang terorganisasi. Pembalakan liar ini dilakukan oleh organisasi - organisasi yang memerlukan sumber daya hutan demi pendapatan pribadi dengan modal minimum tanpa memperdulikan dampak - dampak yang disebabkan. Kegiatan ini berujung pada kerusakan hutan akibat aktivitas penebangan liar yang tidak terpantau karena para pelaku tak jarang menebang dalam jumlah banyak, melakukan penebangan pada hutan lindung, ataupun melakukan pembalakan liar pada area yang dilarang.

Pembalakan liar merupakan salah satu penyebab berkurangnya tutupan hutan di Indonesia sekitar $40 \%$ dalam kurun waktu 50 tahun, sedangkan tutupan hutan berperan penting dalam menjaga keseimbangan ekosistem dan alam disekitarnya. Berdasarkan data Bareskrim Polri, ada terdapat 272 kasus pada 2020, 74 pada tahun 2019, 74 pada tahun 2018, 575 pada tahun 2017 dan 507 pada tahun 2016 tentang kasus pembakalan liar yang ditangani. Dampak buruk yang disebabkan oleh pembalakan liar pada kehidupan manusia berupa banjir, kekeringan, longsor, dan krisis iklim. Selain itu, pembalakan liar juga menimbulkan kerusakan pada ekosistem ekosistem flora dan fauna yang dilindungi, contohnya pada wilayah gambut. Berkurangnya jumlah pohon pada wilayah gambut dapat menyebabkan kekeringan bagi gambut di bawahnya. Pohon berperan penting dalam menjaga kelembaban tanah gambut sehingga lahan gambut tersebut tetap berada dalam kondisi idealnya. Namun jika lahan gambut tersebut mengalami kekeringan akibat evaporasi maka ketinggian tanah akan berkurang sehingga menyebabkan hilangnya cadangan karbon besar pada tanah. Selain itu lahan gambut yang kering sangat mudah untuk terbakar, jika suatu lahan gambut terbakar maka dapat berujung pada kebakaran hutan yang turut mempercepat laju degradasi hutan.

Kota Pekanbaru merupakan salah satu wilayah Provinsi Riau yang mengalami degradasi hutan yang sangat cepat. Sebagian besar faktornya dipengaruhi oleh kebakaran hutan yang seringkali dipicu oleh terbakarnya lahan gambut. Peristiwa ini diakibatkan oleh organisasi - organisasi yang melakukan pembalakan liar dalam jumlah banyak, adapun lahan hasil penebangan tersebut digunakan sebagai lahan perkebunan, lahan sawit, atau dibiarkan begitu saja tanpa melakukan penanaman ulang, sedangkan hasil kayunya diangkut dan didistribusikan secara illegal. Pada tahun 2019, oleh karena maraknya kasus kebakaran hutan dan lahan terjadi bencana kabut asap yang menyelimuti Kota Pekanbaru, bencana ini menyebabkan jarak pandang di Kota Pekanbaru hanya sejauh 300 meter. Selain berkurangnya jarak pandang, warga Kota Pekanbaru banyak tertimpa sakit - penyakit seperti sesak napas, asma, infeksi saluran pernapasan akut (ISPA), iritasi, bronkitis, dll. Musibah ini cukup mengingatkan warga serta pemerintah seberapa berbahanya pembalakan liar bagi ekosistem dan kehidupan manusia walau belum cukup untuk menghentikan praktik tersebut. Demi menghentikan aktivitas illegal tersebut maka diperlukan hukum yang tegas, pasti, dan bersifat memaksa bagi para pihak yang bersangkutan.

Dalam hal regulasi, secara umum praktik pembalakan liar telah diatur dalam Undang - Undang Nomor 18 Tahun 2013 tentang Pencegahan dan Pemberantasan Perusakan Hutan dan UndangUndang Nomor 47 Tahun 1999 tentang Kehutanan sebagaimana diubah dengan Undang-Undang Nomor 19 Tahun 2004 tentang Peraturan Pemerintah Pengganti Undang-Undang Nomor 1 Tahun 2004 tentang Perubahan Atas Undang-Undang Nomor 41 Tahun 1999 tentang Kehutanan menjadi Undang-Undang.

Namun karena adanya kelemahan yang dimiliki oleh Undang - Undang Nomor 41 Tahun 1999 tentang Kehutanan dalam menjerat para pelaku perusakan hutan terutama dalam kasus praktik pembalakan liar, maka dibentuklah Undang - Undang Nomor 18 Tahun 2013 tentang 
Pencegahan dan Pemberantasan Perusakan Hutan demi menjamin kepastian hukum pada bidang pencegahan dan perusakan hutan yang kemudian pada tahun 2020 dilakukan perubahan terhadap pasal - pasal tertentu di dalamnya oleh Undang - Undang Nomor 11 Tahun 2020 tentang Cipta Kerja. Adapun tujuan dari Undang - Undang Nomor 18 Tahun 2013 tentang Pencegahan dan Pemberantasan Perusakan Hutan adalah sebagai berikut: a) Menjamin kepastian hukum dan memberikan efek jera bagi pelaku perusakan hutan; b) Menjamin keberadaan hutan secara berkelanjutan dengan tetap menjaga kelestarian dan tidak merusak lingkungan serta ekosistem sekitarnya; c) Mengoptimalkan pengelolaan dan pemanfaatan hasil hutan dengan memperhatikan keseimbangan fungsi hutan guna terwujudnya masyarakat sejahtera; dan d) Meningkatnya kemampuan dan koordinasi aparat penegak hukum dan pihak-pihak terkait dalam menangani pencegahan dan pemberantasan perusakan hutan. Agar tujuan - tujuan tersebut dapat direalisasikan secara optimal maka hambatan apapun yang dapat melemahkan ataupun menghambat kinerja Undang - Undang Nomor 18 Tahun 2013 tentang Pencegahan dan Pemberantasan Perusakan Hutan harus dapat diidentifikasi dan ditanggulangi. Sehingga dengan hal ini dapat memberikan kepastian hukum yang memadai secara efektif tanpa bertentangan dengan perundang - undangan yang lebih tinggi dan dapat memberikan efek jera bagi para pelaku pembalakan liar serta mengoptimalkan kinerja aparat penegak hukum dan pemerintah dalam menanggulangi praktik pembalakan liar. Dengan demikian tujuan dari penelitian ini adalah: a) Untuk mengetahui bagaimana sinkronisasi Undang - Undang Nomor 18 Tahun 2013 tentang Pencegahan dan Pemberantasan Perusakan Hutan secara vertikal dan horizontal terhadap Undang - Undang Dasar Republik Indonesia Tahun 1945 dengan Undang - Undang sederajat lainnya; b) Untuk mengetahui bagaimana implementasi Undang - Undang Nomor 18 Tahun 2013 tentang Pencegahan dan Pemberantasan Perusakan Hutan terhadap praktik pembalakan liar.

\section{Rumusan Masalah}

Rumusan masalah dalam penelitian ini adalah:

1. Bagaimana sinkronisasi Undang - Undang Nomor 18 Tahun 2013 tentang Pencegahan dan Pemberantasan Perusakan Hutan secara vertikal dan horizontal terhadap Undang - Undang Dasar Republik Indonesia Tahun 1945 dengan Undang - Undang sederajat lainnya?;

2. Bagaimanakah implementasi Undang - Undang Nomor 18 Tahun 2013 tentang Pencegahan dan Pemberantasan Perusakan Hutan terhadap praktik pembalakan liar?

\section{METODE PENELITIAN}

Metode yang digunakan dalam penelitian ini adalah normatif, yaitu penelitian hukum yang berpegang pada segi-segi yuridis dengan mempergunakan sumber bahan hukum seperti bahan hukum primer, antara lain peraturan perundang-undangan, keputusan pengadilan yang sesuai dengan permasalahan dan tujuan penelitian. Bahan hukum yang menjadi bahan sinkronisasi adalah Undang-Undang Dasar Negara Republik Indonesia Tahun 1945, Undang-Undang Nomor 5 Tahun 1960 tentang Peraturan Dasar Pokok-pokok Agraria, Undang-Undang Nomor 41 Tahun 1999 tentang Kehutanan setelah perubahan oleh Undang-Undang Nomor 19 Tahun 2004 tentang Peraturan Pemerintah Pengganti Undang-Undang Nomor 1 Tahun 2004 tentang Perubahan Atas Undang-Undang Nomor 41 Tahun 1999 tentang Kehutanan menjadi Undang-Undang setelah perubahan oleh Undang - Undang No. 11 Tahun 2020 tentang Cipta Kerja, Undang-Undang Nomor 4 Tahun 2009 tentang Pertambangan Mineral dan Batubara setelah perubahan oleh Undang-Undang Nomor 3 Tahun 2020 dan Undang-Undang Nomor 11 Tahun 2020 Cipta Kerja, Undang-Undang Nomor 32 Tahun 2009 tentang Perlindungan dan Pengelolaan Lingkungan 
hidup setelah perubahan oleh Undang-Undang Nomor 11 Tahun 2020 tentang Cipta Kerja, Undang-Undang Nomor 18 Tahun 2013 tentang Pencegahan dan Pemberantasan Perusakan Hutan, Undang-Undang Nomor 17 Tahun 2019 tentang Sumber Daya Air. Selain itu, adapun bahan hukum sekunder yang dapat mendukung penelitian berdasarkan bahan-bahan hukum primer guna menunjang bahan hukum primer, yang dapat berupa jurnal ilmiah, artikel internet, buku teks, dan hasil penelitian sehingga regulasi tentang pencegahan dan pemberantasan terhadap perusakan hutan di wilayah Riau dapat terwujud.

\section{HASIL DAN PEMBAHASAN}

\section{Sinkronisasi Undang - Undang Nomor 18 Tahun 2013 tentang Pencegahan dan Pemberantasan Perusakan Hutan Terhadap Undang - Undang Dasar 1845 dengan Undang - Undang Sederajat Lainnya}

Tujuan dilakukannya sinkronisasi terhadap peraturan perundang - undangan yaitu untuk meneliti keserasian hukum antar hukum positif atau peraturan perundang - undangan yang sederajat maupun dengan peraturan perundang - undangan yang lebih tinggi agar tidak bertentangan berdasarkan hierarki perundang - undangan. Sinkronisasi peraturan perundang - undangan dilakukan dengan dua cara yaitu sinkronisasi vertikal dan horizontal. Sinkronisasi vertikal yaitu jika perundang - undangan yang berlaku untuk suatu bidang tertentu tidak bertentangan antar satu sama lain, jika dilihat dari hierarki perundang - undangan yang berlaku. Sinkronisasi horizontal yaitu tinjauan yang dilakukan pada perundang - undangan yang sederajat dan mengatur bidang yang sama. Dalam hal sinkronisasi vertikal, jika suatu peraturan perundang undangan bertentangan dengan peraturan yang lebih tinggi hirarkinya maka hal tersebut dapat diselesaikan dengan asas hukum Lex Superiori derogat legi Inferiori yaitu peraturan/undang undang yang lebih tinggi mengesampingkan peraturan/undang - undang yang lebih rendah. Sebelum melakukan sinkronisasi maka peraturan perundang - undangan yang menjadi bahan hukum pada suatu penelitian, harus dilakukan inventarisasi terlebih dahulu terhadap peraturan perundang - undangan yang akan dipakai lalu melakukan perbandingan hukum.

\section{Sinkronisasi Vertikal}

Sinkronisasi vertikal dilakukan terhadap perundang - undangan yang berbeda derajat. Hierarki perundang - undangan diatur oleh Undang-Undang Nomor 12 Tahun 2011 tentang Pembentukan Peraturan Perundang-undangan pada Pasal 7 sebagai berikut: a) Undang - Undang Dasar Negara Republik Indonesia Tahun 1945; b) Ketetapan MPR; c) Undang-undang/Peraturan Pemerintah Pengganti Undang-Undang; d) Peraturan Pemerintah; e) Peraturan Presiden; f) Peraturan Daerah Provinsi; g) Peraturan Daerah Kabupaten/Kota. Bahan - bahan hukum primer yang dijadikan objek penelitian sesuai dengan urutan peraturan perundang - undangan yang tersebut ialah Undang-Undang Dasar Negara Republik Indonesia Tahun 1945 dan Undang Undang Nomor 18 Tahun 2013 tentang Pencegahan dan Pemberantasan Perusakan Hutan. Oleh karena itu sinkronisasi vertikal dilakukan terhadap UUD 1945 dengan UU No. 18 Tahun 2013 tentang Pencegahan dan Pemberantasan Perusakan Hutan.

Pada UUD 1945, yang mengatur tentang lingkungan ada pada Pasal $28 \mathrm{H}$ ayat (1) mengenai hak rakyat untuk mendapatkan lingkungan hidup yang baik dan Pasal 33 ayat (3) yang mengatur tentang bumi dan air dan kekayaan alam yang terkandung didalamnya dikuasai oleh negara dan dipergunakan sebesar-besar untuk kemakmuran rakyat. Pasal 28H ayat (1) mencantumkan secara jelas bahwa tiap-tiap rakyat berhak mendapatkan lingkungan hidup yang baik. Hak tersebut merupakan salah satu bagian dari hak asasi manusia (HAM) yang berhak direalisasikan. Dengan adanya pasal ini sebagai jaminan konstitusional maka praktik-praktik yang berkaitan dengan perusakan hutan yang oleh karenanya menghambat masyarakat menerima lingkungan hidup yang baik, merupakan pelanggaran terhadap UUD 1945. 
Pasal 33 ayat (3) mengatur tentang bumi dan air dan kekayaan alam yang terkandung didalamnya dikuasai oleh negara dan dipergunakan sebesar - besar untuk kemakmuran rakyat. Dengan adanya pasal ini maka seluruh objek pembalakan liar yakni yang terkandung di dalam bumi maupun yang termasuk kekayaan alam dikuasai oleh negara. Makna "dikuasai oleh negara" tertuang di dalam Putusan Mahkamah Konstitusi Perkara Nomor 002/PUU-I/2003. Telah dinyatakan di dalam putusan tersebut bahwa pengertian ini haruslah mencakup makna penguasaan yang bersumber dari konsep kedaulatan rakyat, yang artinya segala hal yang mencakup bumi, air, dan kekayaan alam adalah milik rakyat yang dimandatkan kepada negara untuk mengadakan kebijakan (beleid) dan pengurusan (berstuursdaad), pengaturan (regelendaad), pengelolaan (beheersdaad), dan pengawasan (toezichthoudensdaad) dengan tujuan untuk sebesar - besarnya memakmurkan rakyat. Pembalakan liar merupakan salah satu praktik perusakan hutan yang memiliki andil dalam menurunkan kemakmuran rakyat akibat kerugian - kerugian yang disebabkan, artinya berdasarkan Pasal 33 ayat (3) dalam UUD 1945, pembalakan liar adalah suatu tindakan yang dilarang dan pemerintah memiliki hak untuk mengadakan kebijakan seperti membuat regulasi terkait pembalakan liar dan pengaturan terhadap pelaku seperti mencabut fasilitas perizinan ataupun kewenangannya dalam hal apapun yang berkaitan.

Mengenai sinkronisasi secara vertikal antara UUD 1945 dengan UU No. 18 Tahun 2013 tentang Pencegahan dan Pemberantasan Perusakan Hutan, diuraikan sebagai berikut. Setelah penafsiran pasal-pasal dalam UUD 1945, maka praktik pembalakan liar yang ikut berperan dalam perusakan hutan adalah perbuatan terlarang yang turut merampas hak asasi rakyat dan dalam hal ini pemerintah berhak mengadakan kebijakan dan pengurusan, pengaturan, pengelolaan, dan pengawasan terkait praktik - praktik tersebut.

Dengan begitu, dapat disimpulkan bahwa UU No. 18 Tahun 2013 yang mengatur mengenai pencegahan dan pemberantasan perusakan hutan telah sinkron secara vertikal dengan UUD 1945 dan tidak bertentangan.

\section{Sinkronisasi Horizontal}

Sinkronisasi horizontal bertujuan untuk meninjau perundang-undangan yang sederajat dan mengatur bidang yang sama. Dalam sinkronisasi horizontal ini, peraturan perundang-undangan yang akan di sinkronisasi adalah mengenai perlindungan hutan dan pencegahan pembalakan liar terhadap Undang-Undang lainnya sebagaimana yang tertera pada bagian metode penelitian pada bahan hukum yang dipakai kecuali UUD 1945.

Pada UU No. 18 Tahun 2013 telah diatur secara tegas dan jelas mengenai perbuatan-perbuatan yang dilarang pada Pasal 12, Pasal 13, Pasal 14, Pasal 15, Pasal 16, Pasal 17, Pasal 19, Pasal 20, Pasal 21, Pasal, 22, Pasal 23, Pasal 24, Pasal 25, Pasal 26, dan Pasal 28. Pasal 12 sampai dengan Pasal 17 serta Pasal 19 sampai dengan Pasal 26 mengatur mengenai perbuatan orang yang dilarang dalam artian masyarakat sedangkan Pasal 28 mengatur mengenai perbuatan pejabat yang dilarang. Perbuatan-perbuatan yang dilarang pada UU No. 18 Tahun 2013 berkaitan dengan ada atau tidaknya izin oleh pemerintah terkait praktik kehutanan yang akan dilakukan, dengan kata lain, selama izin tersebut ada dan tidak disalahgunakan maka perbuatan tersebut legal. Dalam pasal ini, ketentuan mengenai pembalakan liar terkhusus pada praktik pembalakan liar diatur pada Pasal 87. Isi pasal ini terdiri dari tindak pidana bagi orang perseorangan yang sengaja melakukan tertera pada ayat (1), orang perseorangan yang karena kelalaiannya tertera pada ayat (2), dan korporasi sebagai subjek hukum tindak pidana pembalakan liar tertera pada ayat (4).

UU No. 18 Tahun 2013 dalam pengubahannya oleh UU Cipta Kerja telah mengurangi eksistensi Hak Ulayat yang dimiliki oleh masyarakat hukum adat setelah ditambahkan pasal sisipan yaitu Pasal 12A dan Pasal 17A yang menerapkan sanksi administratif bagi orang perorangan yang bertempat tinggal di dalam atau di sekitar wilayah hutan. Peraturan ini tidak sinkron dengan UU 
Pokok Agraria (UUPA) yang mengakui adanya Hak Ulayat dengan dua syarat mengenai eksistensinya sebagaimana tercantum pada Pasal 3 UUPA, "sepanjang menurut kenyataannya masih ada". Berkurannya eksistensi tersebut menyebabkan kurangnya peran masyarakat adat dalam pengelolaan hutan dan alam, pelestarian hutan oleh masyarakat adat dapat dibuktikan oleh suku Baduy yang tidak mengeksploitasi hutan sebab adanya tradisi pengelolaan hutan. Peratuan ini juga menyebabkan hilangnya permintaan persetujuan oleh korporasi-korporasi yang hendak mengelola area hutan tertentu terhadap masyarakat hukum adat yang tinggal pada area yang dimaksudkan. Malah sebaliknya, UU No. 18 Tahun 2013 dapat digunakan sebagai "serangan balik" terhadap masyarakat adat tersebut.

Adapun UUPA mengatur tentang hak atas tanah atas dasar hak menguasai dari Negara pada Pasal 2 yang diatur pada Pasal 4 ayat (2), pasal ini memberi wewenang untuk mempergunakan tanah yang bersangkutan, tubuh bumi, dan air serta ruang yang ada diatasnya. Hak atas tanah ini dapat berlaku hak milik sebagai hak turun-temurun, terkuat dan ter- penuh yang dapat dipunyai oleh orang atas tanah tersebut, begitu pula dengan hak guna-usaha, hak guna-bangunan, dan hakpakai, hak sewa. Hak-hak atas tanah ini pun dapat disalahgunakan terutama jika tanah yang dimaksud adalah kawasan hutan, terutama kawasan hutan yang terdapat pemukiman masyarakat adat.

Adapun pada UU Nomor 17 tahun 2019 tentang Sumber Daya Air yang menyangkut tentang kehutanan tertulis pada Pasal 26 ayat (1) mengenai pelaksanaan konservasi Sumber Daya Air salah satunya pada kawasan hutan, serta pada ayat (2) yang memaksudkan pelaksanaan konservasi tersebut berdasarkan undang-undang. Mengenai "pertanian rakyat" yang diatur pada Pasal 8 ayat (2) huruf $b$, yang dimaksud adalah budi daya peranian yang meliputi berbagai komoditas, salah satunya kehutanan yang dikelola oleh rakyat dengan luas tertentu. Peraturan tersebut masih sinkron dengan peraturan kehutanan dalam rangka membudidayakan serta merawat kawasan hutan.

Undang-Undang Nomor 4 Tahun 2009 tentang Pertambangan Mineral dan Batubara setelah perubahan oleh Undang-Undang Nomor 3 Tahun 2020 dan Undang-Undang Nomor 11 Tahun 2020 Cipta Kerja tidak secara spesifik mengatur tentang kehutanan namun terdapat faktor membahayakan dalam regulasinya dalam ketentuan mengenai wilayah yang dapat diusahakan sebagaimana yang tercantum pada Pasal 27 ayat (2) yang menyatakan bahwa Wilayah Pencadangan Negara (WPN) dapat diusahakan sebagian atau seluruh luas wilayahnya jika telah mendapat persetujuam DPR, maksud dari WPN ini ialah wilayah-wilayah konservasi yang salah satunya adalah hutan lindung.

Adapun tertera di dalam undang - undang setelah perubahan mengenai perbuatan yang dilarang tercantum pada Pasal 50 ayat (1), ayat (2), dan ayat (3). Pasal 50 ayat (1) mengatur tentang pelarangan kegiatan yang dapat menimbulkan kerusakan hutan bagi setiap orang yang telah diberi perizinan berusaha. Tentang perbuatan yang mengerjakan, menggunakan, dan/atau menduduki kawasan hutan secara ilegal terdapat pada Pasal 50 ayat (2) huruf a Tentang perbuatan yang memungut atau memanen hasil hutan secara ilegal tercantum pada Pasal 50 ayat (2) huruf c. Makna "hasil hutan" dalam pasal 50 ayat (2) huruf c termasuk hasil dari pohon pohon yang tumbuh di dalam kawasan hutan yaitu kayu - kayuan sebagaimana yang tertuang pada Pasal 1 angka 13 bahwa hasil hutan adalah benda - benda hayati, nonhayati dan turunannya, serta jasa yang berasal dari hutan. Mengenai pelanggaran yang tercantum pada Pasal 50 ayat (2) huruf $\mathrm{c}$ terhadap orang perseorangan ataupun kelompok masyarakat yang bertempat tinggal di sekitar kawasan hutan maka berdasarkan Pasal 50A ayat (1). Pada Pasal 50 ayat (2) huruf g mengatur tentang perbuatan yang dilarang dengan membawa, mengeluarkan, dan mengangkut tumbuh - tumbuhan yang tidak dilindungi undang - undang keluar dari kawasan hutan tanpa perizinan dari pejabat yang berwenang. Adapun mengenai UU kehutanan No. 41 Tahun 1999 setelah perubahan oleh UU Cipta Kerja membawa resiko pembalakan liar yang 
berujung pada degradasi hutan di Indonesia sebab hilangnya ketentuan Pasal 18 mengenai ketetapan mempertahankan 30\% dari luas daerah aliran sungai. Serta dihapusnya kewenangan DPR dalam persetujuan mengenai perubahan kawasan hutan yang sebelumnya tercantum pada Pasal 19.

Undang-Undang Nomor 32 Tahun 2009 tentang Perlindungan dan Pengelolaan Lingkungan hidup setelah perubahan oleh Undang-Undang Nomor 11 Tahun 2020 tentang Cipta Kerja menghapuskan Komisi Penilai Amdal yang digantikan oleh Lembaga Uji Kelayakan Pemerintah Pusat pada Pasal 24, sehingga dengan ini menimbulkan dampak tidak adanya ikut serta masyarakat dalam lembaga uji tersebut, perlu diingat bahwa masyarakat sebagai pihak yang setara dengan hukum sehingga berhak untuk berpartisipasi dalam pengambilan keputusan yang mempengaruhi hajat hidupnya. Adapun mengenai pelestarian hutan lindung maupun hutan di luar hutan lindung tercantum pada Pasal 1 ayat (2) mengenai upaya yang harus dilakukan demi melestarikan fungsi lingkungan hidup dan mencegah terjadinya pencemaran lingkungan hidup.

Mengenai sinkronisasi horizontal antar undang-undang diatas mengenai perlindungan hutan dan pencegahan pembalakan liar masih banyak ketidaksinkronan antar undang-undang terutama dalam perihal memfokuskan pada pelestarian hutan. Ketidaksinkronan antar UU Minerba yang bertentangan dengan UU No. 18 Tahun 2013 yang melarang pertambangan pada hutan lindung menimbulkan ketidakpastian hukum serta minimnya perlindungan bagi hutan lindung dan kawasan hutan yang tersisa, sama perihalnya dengan UUPA yang turut bertentangan dengan UU NO. 18 Tahun 2013 mengenai pengakuan hutan adat bagi masyarakat hukum adat. Perihal berikut pada UUPA turut dilakukan oleh UU tentang Perlindungan dan Pengelolaan Lingkungan hidup yang menghilangkan andil masyarakat dalam partisipasi uji kelayakan lingkungan hidup berarti turut menghilangkan suara masyarakat dalam menyuarakan pendapat mengenai pengelolaan hutan di dalam kawasan yang dimaksud.

\section{Implementasi UU No 18 tahun 2013 terhadap praktek illegal logging di kota Pekanbaru}

Pembalakan liar merupakan salah bentuk dari perusakan hutan. Hal ini sesuai dengan pengertian perusakan hutan dalam Pasal 1 angka 3 Undang-Undang Nomor 18 Tahun 2013 tentang Pencegahan dan Pemberantasan Perusakan Hutan, yakni : "Perusakan hutan adalah proses, cara, atau perbuatan merusak hutan melalui kegiatan pembalakan liar, penggunaan kawasan hutan tanpa izin atau penggunaan izin yang bertentangan dengan maksud dan tujuan pemberian izin di dalam kawasan hutan yang telah ditetapkan, yang telah ditunjuk, ataupun yang sedang diproses penetapannya oleh Pemerintah”.

Pemberantasan tindak pembalakan liar atau Illegal logging telah diatur dalam Undang-Undang Republik Indonesia Nomor 18 Tahun 2013 tentang Pencegahan dan Pemberantasan Perusakan Hutan setelah perubahan oleh Undang-Undang Nomor 11 Tahun 2020 tentang Cipta Kerja pada Pasal 12 huruf a adalah melakukan tindakan penebangan pohon, dalam kawasan hutan dan tidak sesuai dengan Perizinan Berusaha. Sebagaimana yang dimaksud mengenai definisi dari Perizinan Berusaha berdasarkan Peraturan Pemerintah Nomor 23 Tahun 2021 Tentang Penyelenggaraan Kehutanan merupakan legalitas untuk pelaku usaha untuk memulai dan menjalankan usaha dan/atau kegiatannya yang berupa Perizinan Berusaha Pemanfaatan Hutan dan Perizinan Berusaha Pengolahan Hasil Hutan. Bersamaan dengan Pasal 14 ayat 2 Peraturan Pemerintah Nomor 60 Tahun 2009 tentang Perlindungan Hutan bahwasanya yang termasuk dalam kegiatan pemanfaatan hutan tanpa izin, antara lain pemegang izin melakukan pemanfaatan hutan diluar areal yang diberikan izin; pemegang izin melakukan penangkapan/pengumpulan flora fauna melebihi target/quota yang telah ditetapkan; pemegang izin melakukan pemanfaatan hutan dalam radius dari lokasi tertentu yang dilarang undang-undang.

Apabila izin pemanfaatan hutan dipergunakan tidak sesuai dengan peraturan yang telah ditetapkan, maka dapat dinyatakan perbuatan tersebut telah melakukan tindak pidana yang 
terdapat didalam Pasal 12 huruf b yaitu melakukan penebangan pohon dalam kawasan hutan tanpa memiliki Perizinan Berusaha dari Pemerintah Pusat, maka dapat dimaknai bahwasanya izin yang dimiliki bersifat ilegal. Pasal 12 huruf c yaitu menebang pohon dalam kawasan hutan secara tidak sah. Menurut KBBI, sah didefinisikan sebagai tindakan menurut hukum; diakui kebenarannya; diakui oleh pihak resmi. Berdasarkan Pasal 12 huruf c, menebang, secara tidak sah dapat dimaknai bahwa orang melakukan tindakan yang melawan hukum.

Pada Undang-Undang Nomor 18 Tahun 2013 Pasal 13 juga mengatur mengenai penebangan pohon dalam kawasan hutan secara tidak sah dengan radius atau jarak dalam kawasan hutan guna menjaga ekosistem lingkungan hutan demi kepentingan masyarakat sekitar kawasan hutan. Namun pada Pasal 13 ayat 2 terdapat pengecualian terhadap Pasal 13 ayat 1 yaitu apabila kegiatan yang mempunyai tujuan strategis yang tidak dapat dihindari dengan mendapat izin khusus dari Menteri. Kegiatan yang dimaksudkan dapat berupa kegiatan darurat demi kepentingan negara, pertumbuhan ekonomi, sosial, budaya, maupun pertahanan keamanan negara. Sebagai contoh berdasarkan Peraturan Pemerintah Nomor 105 tahun 2015 Pasal 4 mengenai kepentingan pembangunan di luar kegiatan kehutanan huruf e adalah pembangunan jalan tol, jalan umum dan jalur kereta api. Pasal 12 huruf d setelah perubahan oleh UndangUndang Nomor 11 Tahun 2020, berisi ketentuan bahwa seseorang dilarang secara sengaja memuat, membongkar, mengeluarkan, mengangkut, menguasai dan/atau memiliki hasil penebangan di kawasan hutan tanpa Perizinan Berusaha dari Pemerintah Pusat. Pasal 12 huruf e mengenai seseorang yang secara sengaja mengangkut, menguasai, atau memiliki hasil hutan kayu tanpa dilengkapi surat keterangan sah. Sebagaimana juga diatur dalam Undang-Undang Nomor 41 Tahun 1999 tentang Kehutanan, Pasal 50 Ayat (3) huruf h, mengenai apa yang dimaksud dengan "dilengkapi bersama-sama" adalah bahwa seseorang yang melakukan perbuatan pengangkutan, penguasaan, atau pemilikan hasil hutan maka harus dilengkapi dengan surat-surat yang sah sebagai bukti, seperti dokumen surat keterangan mengenai jenis, jumlah, volume hasil hutan yang diangkut.

Sebagaimana tertera dalam Undang-Undang Nomor 18 Tahun 2013 tentang Pencegahan dan Pemberantasan Perusakan Hutan pasal 1 ayat (4) dinyatakan bahwa illegal logging adalah semua kegiatan pemanfaatan hasil hutan kayu secara tidak sah yang terorganisir. Maka dari itu, dapat dikatakan subjek hukum undang-undang tersebut adalah perusahaan-perusahaan atau pribadipribadi yang melakukan pelanggaran hukum dengan menebang pohon-pohon atas dasar keperluan pribadi dan melakukan pemanfaatan tanpa izin, membuka lahan dan menguras habis isinya, tanpa melakukan penanaman kembali maka akan menerima akibat hukum agar memberi efek jera bagi pelaku sebagaimana tertera dalam Undang-Undang Nomor 18 tahun 2013 Pasal 18 ayat (1), dan didukung dengan Undang-Undang Nomor 41 Tahun 1999 Jo Undang-Undang Nomor 19 Tahun 2004 bahwa terhadap pelaku pelanggar hukum dibidang kehutanan diberikan sanksi pidana dan sanksi administrasi yang berat.

Dalam Undang-Undang Nomor 11 tahun 2020, Pasal 82 Nomor 1 mengenai akibat hukum bagi orang perseorangan yang melakukan tindak pidana pada Pasal 12 huruf a, b dan c, dipidana dengan pidana penjara paling singkat 1 tahun dan paling lama 5 tahun dan pidana denda paling sedikit ayat Rp 500.000.000,00 dan paling banyak Rp 2.500.000.000,00. Berdasarkan ayat 2, mengenai akibat hukum terhadap orang perseorangan yang tinggal di dalam kawasan hutan kurang dari 5 (lima) tahun dan tidak terus menerus, dikenakan pidana penjara paling singkat 3(tiga) bulan dan paling lama 2 (dua) tahun dan/atau pidana denda paling sedikit Rp 500.000,00 dan paling banyak Rp 500.000.000,00. Ayat 3 adalah akibat hukum terhadap korporasi yang melakukan tindakan melawan hukum, bagi pengurusnya dikenakan sanksi pidana penjara paling singkat 5 (lima) tahun dan paling lama 15 (lima belas) tahun dan pidana denda paling sedikit Rp5.000.000.000,00 dan paling banyak Rp15.000.000.000,00 dan/atau korporasi dikenakan pemberatan $1 / 3$ dari denda pidana yang dijatuhkan. Dalam Undang-Undang Nomor 11 Tahun 
2020 adanya penambahan ketentuan yaitu Pasal 12 A ayat (1) dimana orang perseorangan yang bertempat tinggal didalam dan/atau di sekitar kawasan hutan paling singkat 5 (lima) tahun secara terus menerus yang melakukan pelanggaran terhadap ketentuan Pasal 12 huruf a sampai dengan huruf $f$ dan/atau h dikenakan sanksi administratif. Tetapi pada Pasal 12A ayat (2) mengandung pengecualian terhadap orang yang tinggal di kawasan hutan paling singkat 5 (lima) tahun secara terus menerus dan telah terdaftar dalam kebijakan penataan kawasan hutan dan pengecualian terhadap orang yang telah mendapatkan sanksi sosial.

Majelis Hakim dalam menjatuhkan Putusan terhadap tindak pidana illegal logging di Pengadilan Negeri Pekanbaru bergantung pada alat bukti, barang bukti,dan saksi sebagai pembuktian di persidangan agar dapat menerapkan sanksi pidana. Barang bukti tindak pidana kehutanan relatif mudah untuk diungkap apabila aparat penegak hukum dapat bekerja dengan cepat dan professional karena barang buktinya agak susah untuk dihilangkan khususnya apabila terkait dengan kawasan hutan dan apabila terkait dengan hasil hutan maka memerlukan sarana alat angkut yang memadai serta butuh waktu untuk memindahkannya. Tercatat pada tahun 2017 yang lalu, ada sederet kasus penebangan hutan secara liar yang terjadi di Kota Pekanbaru. Berdasarkan Putusan PT Pekanbaru Nomor 103/PID/SUS-LH/2017/PT.PBR tanggal 7 Juli 2017, menyatakan terdakwa Ilyas Bin Syafarudin telah terbukti secara sah dan meyakinkan bersalah melakukan tindak pidana menguasai, memiliki kayu hasil hutan yang tidak dilengkapi secara bersama Surat Keterangan Sahnya Hasil Hutan sebagaimana terdakwa telah melanggar ketentuan Undang-Undang Nomor 18 Tahun 2013 Pasal 12 huruf e. Dalam hal ini, terdakwa diadili dengan dijatuhkan pidana penjara selama 1 (satu) tahun dan 6 (enam) bulan dan Denda sejumlah Rp 500.000.000,00 (lima ratus juta Rupiah) dengan ketentuan jika denda tersebut tidak dibayar oleh Terdakwa, akan diganti dengan 3 (tiga) bulan kurungan.

Selain kasus pada tahun 2017, terjadi juga kasus dimana terdakwa Paul Stephen Cottrell Dormer terbukti bersalah karena melakukan tindakan pidana yaitu sengaja menerima hasil hutan yang diketahui berasal dari pembalakan liar, karena terdakwa sengaja menerima hasil dari pembalakan liar tersebut maka terdakwa dijatuhi pidana penjara selama 1 tahun dan denda sebesar Rp 500 juta, dengan ketentuan apabila denda tersebut tidak dibayar maka diganti 3 bulan penjara. Selain itu juga ditemukannya barang bukti seperti mesin serut kayu merk AKS-LX500 warna biru putih , mesin planer kayu merk AKS-CG16P warna putih, serta 16 lembar laporan bukti penerimaan kayu yang diterima oleh pihak PT. Pulau Bawah.

Pentingnya Penegakan Hukum Pidana dalam mengatasi Illegal logging, sangat berpengaruh terhadap kepentingan ekosistem hutan dan juga terhadap masyarakat, maka dari itu pertimbangan hakim akan pelaku pembalakan liar haruslah berupa sanksi yang mampu membuat masyarakat menghindari perbuatan melawan hukum.

\section{KESIMPULAN DAN SARAN}

Penegakan Hukum terhadap pelaku kejahatan pembalakan liar (Illegal Logging) diatur dalam Undang-Undang Nomor 18 Tahun 2013 tentang Pencegahan dan Pemberantasan Perusakan Hutan yang telah diperbarui oleh Undang-Undang Nomor 11 Tahun 2020 tentang Cipta Kerja. Hutan lindung serta hutan non-lindung beresiko terkena deforestasi karena minimnya kepastian hukum yang melindungi hutan-hutan tersebut akibat banyaknya undang-undang yang mengatur mengenai usaha-usaha di atas wilayah hutan bertentangan antar satu sama lain. Maka dari itu, sangat diperlukan sinkronisasi antar peraturan perundang-undangan terutama dalam perihal kehutanan. Selain itu, dalam perihal pelestarian hutan akibat pembalakan liar haruslah ada ikut campur masyarakat setempat dalam pengelolaannya, terutama dalam menyuarakan pendapat mereka mengenai pemfungsian hutan yang akan dikelola. Pasal 12 Undang-Undang Nomor 18 Tahun 2013 tentang Pencegahan dan Pemberantasan Perusakan Hutan mengatur tentang ketentuan terhadap perbuatan pemanfaatan kayu hasil hutan apabila tidak dilengkapi dengan izin 
pihak berwenang maka akan dikenakan ancaman hukuman. Sanksi Pidana terhadap pelaku tindak pidana termaktub dalam Pasal 50 Undang-undang Nomor 41 Tahun 1999 yang telah diperbarui oleh Undang-undang Nomor 11 Tahun 2020 dalam Pasal 82 mengenai sanksi hukum baik terhadap perseorangan (pribadi) maupun badan usaha (korporasi) yang melakukan tindak pidana. Meskipun demikian, faktanya kebijakan dan peraturan yang ada belum cukup untuk mengatasi permasalahan yang diikuti perkembangan teknologi, dimana pelaku tindak pidana lebih canggih. Dan pengadilan tampak masih kerap melepaskan kasus pelaku tindak pidana pembalakan liar ( illegal logging) sehingga menampilkan rendahnya penegakkan hukum terhadap pelaku tindak pidana yang dimana kurang memberikan efek jera bagi para pelaku.

\section{Saran}

Adapun saran yang dapat peneliti berikan setelah melakukan penelitian terhadap masalah implementasi UU No. 18 Tahun 2013 terhadap praktik pembalakan liar adalah sebagai berikut:

1. Mengenai peraturan perundang-undangan yang mengatur sektor kehutanan serta sektorsektor lainnya yang menggunakan kawasan hutan, maka haruslah dilakukan sinkronisasi terlebih dahulu terhadap peraturan yang lebih tinggi serta peraturan yang bersifat umum agar tidak terjadi pertentangan.

2. Mengenai masalah pembalakan liar, maka tidak cukup hanya aparat penegak hukum yang bekerja melainkan ikut andil masyarakat setempat maupun masyarakat hukum adat dalam penjagaan hutan sangatlah penting untuk diimplementasikan.

\section{REFERENSI}

Muhaimin. (2020). Metode Penelitian Hukum. Mataram University Press, Mataram.

Soekanto, Soerjono. (2015). Penelitian Hukum Normatif: Suatu Tinjauan Singkat. Rajawali Pers, Depok.

Rosidah, Zaidah Nur. (2013). Sinkronisasi Peraturan Perundang-undangan Mengenai Perkawinan Beda Agama. Jurnal Pemikiran Hukum Islam, hal. 16.

Suryani, Ita. (2014). Menggali Keindahan Alam dan Kearifan Lokal Suku Baduy (Studi Kasus Pada Acara Feature Dokumenter "Indonesia Bagus" di Stasiun Televisi NET. TV). Jurnal Musawa, hal 180.

Undang-Undang Dasar Negara Republik Indonesia Tahun 1945

Undang-Undang Nomor 5 Tahun 1960 tentang Peraturan Dasar Pokok-pokok Agraria (Lembaran Negara No. 104 tahun 1960, Tambahan Berita Negara No. 2043)

Undang-Undang Nomor 41 Tahun 1999 tentang Kehutanan (Lembaran Negara No. 167 tahun 1999, Tambahan Berita Negara No. 3888)

Undang-Undang Nomor 19 Tahun 2004 tentang Penetapan Peraturan Pemerintah Pengganti Undang-Undang Nomor 1 Tahun 2004 tentang Perubahan atas Undang-Undang Nomor 41 Tahun 1999 tentang Kehutanan Menjadi Undang-Undang (Lembaran Negara No. 86 tahun 2004, Tambahan Berita Negara No. 4412)

Peraturan Pemerintah Pengganti Undang-Undang Nomor 1 Tahun 2004 tentang Perubahan Atas Undang-Undang Nomor 41 Tahun 1999 tentang Kehutanan menjadi Undang-Undang (Lembaran Negara No. 29 tahun 2004, Tambahan Berita Negara No. 4374)

Undang - Undang No. 11 Tahun 2020 tentang Cipta Kerja (Lembaran Negara No. 245 tahun 2020, Tambahan Berita Negara No. 6573)

Undang-Undang Nomor 4 Tahun 2009 tentang Pertambangan Mineral dan Batubara (Lembaran Negara No. 4 tahun 2009, Tambahan Berita Negara No. 4959)

Undang-Undang Nomor 3 Tahun 2020 tentang Perubahan atas Undang-Undang Nomor 4 Tahun 2009 tentang Pertambangan Mineral dan Batubara (Lembaran Negara No. 147 tahun 2020, Tambahan Berita Negara No. 6525) 


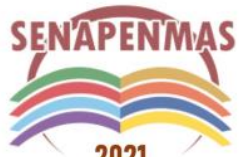

2021
Seminar Nasional Hasil Penelitian dan Pengabdian Kepada Masyarakat 2021

Pengembangan Ekonomi Bangsa Melalui Inovasi Digital Hasil Penelitian dan Pengabdian Kepada Masyarakat Jakarta, 21 Oktober 2021

Undang-Undang Nomor 32 Tahun 2009 tentang Perlindungan dan Pengelolaan Lingkungan hidup (Lembaran Negara No. 140 tahun 2009, Tambahan Berita Negara No. 5059)

Undang-Undang Nomor 18 Tahun 2013 tentang Pencegahan dan Pemberantasan Perusakan Hutan (Lembaran Negara No. 130 tahun 2013, Tambahan Berita Negara No. 5432)

Undang-Undang Nomor 17 Tahun 2019 tentang Sumber Daya Air (Lembaran Negara No.

190 tahun 2019, Tambahan Berita Negara No. 6405) Salim, Agus, "Pengusahaan Migas di Indonesia dalam Perspektif Kedaulatan Negara Atas

SDA (2): Makna "Dikuasai Oleh Negara"”, https://www.esdm.go.id/id/media-center/arsipberita/pengusahaan-migas-di-indonesia-dalam-perspektif-kedaulatan-negara-atas-sda-2makna-dikuasai-oleh-negara, diakses tanggal 05 September 2021.

Tanjung, Chaidir Anwar, "Asap Kian Pekat, Jarak Pandang Hanya 300 Meter di

Pekanbaru”, https://news.detik.com/berita/d-4704573/asap-kian-pekat-jarak-pandang-hanya300-meter-di-pekanbaru, diakses pada 04 September 2021.

Hasan B, "Periode 2018-2019, Indonesia Kehilangan Hutan 462.400 Ha Akibat Konversi dan Karhutla”, https://www.goriau.com/berita/baca/periode-20182019-indonesia-kehilanganhutan-462400-ha-akibat-konversi-dan-karhutla.html, diakses pada 04 September 2021. 
(halaman kosong) 